\title{
Climate-growth relationships and pointer year analysis of a Siberian larch (Larix sibirica Ledeb.) chronology from the Mongolian mountain forest steppe compared to white birch (Betula platyphylla Sukaczev)
}

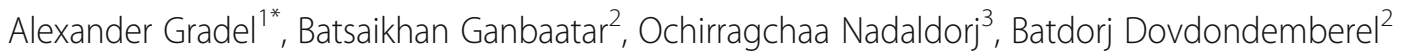
and Antonin Kusbach ${ }^{4}$

\begin{abstract}
Background: Forest area, stand quality and growth of Siberian larch in Mongolia have decreased significantly over recent decades. This forest decline is frequently attributed to factors such as unregulated logging, increased ecological disturbances (primarily fire) and climate change. In this study, we analyzed climate-growth response and pointer years for Siberian larch observed in the Altansumber forest research area in the Mongolian mountain forest steppe zone. We compare our results with previously published results of white birch from the same area.

Methods: We built a reference chronology from wood core samples taken from 30 trees in three neighboring larch stands. Climate-growth relationships were analyzed monthly and seasonally over the period 1962-2009 using climate data from the Eroo weather station. Pointer year analysis covered the same time frame.

Results: Our analysis of the larch chronology showed that precipitation during autumn of the previous year and directly before the growing season of the current year was the most decisive factor determining tree-ring growth. Regional pointer year analysis further indicated that a humid summer and autumn followed by a warm spring support current-year tree-ring growth in these larch stands. Our findings were comparable to a white birch study in the same area. The larch trees, however, showed stronger growth performance and were more tolerant of higher temperatures, notably in spring during peak fire season.

Conclusions: Water availability is the decisive factor for larch growth in the mountain forest steppe zone. The chronologies showed no climatic indication of insect infestations. Differences in climate-growth relationships of birch and larch trees during peak fire season may to some degree be explained by their respective means of protecting themselves against low-intensity surface fires (e.g. thick bark of larch). These fire events occur regularly in the region and are influenced by climatic factors. Our analysis and comparison of climate tree-growth relationships may be valuable for developing climate- and disturbance-resilient forestry practices in Mongolian mountain forest ecosystems.
\end{abstract}

Keywords: Siberian larch, Mountain forest steppe zone, Mongolia, Climate-growth relationship, Pointer years, White birch, Forest fires

\footnotetext{
* Correspondence: alexander.gradel@forst.uni-goettingen.de

${ }^{1}$ Department of Silviculture and Forest Ecology of the Temperate Zones,

Universität Göttingen, Büsgenweg 1, 37077 Göttingen, Germany

Full list of author information is available at the end of the article
} 


\section{Background}

The genus Larix Mill. is widely distributed over the boreal forest biome of the Northern hemisphere. It dominates the Eurasian light taiga forests, especially in Eastern Siberia and Northern Mongolia (Martinsson and Lesinski 2007; Dorjsuren 2014). Larch is shade intolerant and typically grows in clay soils with relatively high $\mathrm{pH}$ levels and limestone content (Martinsson and Lesinski 2007; Kraznoshekov 2013; Tikhonova et al. 2014). Larch is able to survive in regions characterized by extreme cold temperatures (Antropov et al. 2013). Climate conditions characterized by rapid seasonal transition from cold winters to spring combined with sufficient monthly soil moisture levels and short but intensely warm summers are considered favorable for Siberian larch (Larix sibirica Ledeb.) (Martinsson and Lesinski 2007).

Siberian larch is one of the prevailing wood species in forests of the distinctive mountain forest steppe in Northern Mongolian, a transition zone between the northern boreal forest of the Siberian taiga to the dry steppes of Inner Asia (Mühlenberg et al. 2012). Sun exposure and other microclimatic conditions combined with the prevailing disturbance regime, which is fire (MET 2016), are decisive factors for site-specific vegetation: the northern slopes are largely forested, whereas the southern slopes are dominated by steppe vegetation. Certain landscape features can either soften or pronounce the local effects of climatic factors on vegetation. Landscape features in connection with vegetation and ground cover also play an important role in the protection of discontinuous permafrost and water runoff (Swanson 1996; Kopp et al. 2014, 2016).

It is well-established that the Earth's climate is currently changing (IPCC 2013). The effects of climate change in Mongolia have been particularly severe where rising average temperatures are among the highest in the world (Oyuntuya et al. 2015). The pronounced effects of ongoing and projected climatic changes have drawn attention to the vulnerability of boreal and temperate forest ecosystems throughout Eurasia (Lindner et al. 2010; Cui et al. 2016). Moreover, numerous natural forest sites in Northern Mongolia have degraded over past decades and the overall forest area has decreased (Hansen et al. 2013; Khishigjargal et al. 2014). In addition to increasing anthropogenic pressures such as logging and livestock breeding, global climate change is expected to influence the future distribution, composition and structure of forests in Mongolia, and have an impact on larch forests in particular (Dulamsuren et al. 2011; Natsagdorj 2014). According to the National Forest Inventory, larch and birch forests together represent more than $70 \%$ of the total forest land area in Northern Mongolia (MET 2016). Siberian larch represents Mongolia's most important commercial tree species and projections of increasing disturbance frequency, such as recently observed forest fires and insect outbreaks, raise important concerns (Dulamsuren et al. 2010a, 2014; Khishigjargal et al. 2014).

The disturbance-prone mountain forest steppe zone represents the southern distribution border for Siberian larch in Mongolia, where it is often associated with white birch (Betula platyphylla Sukaczev). In recently disturbed forest sites, birch and larch can be found growing within the same valley as pure, single-species stands, or as mixed-species stands. In regions of the Selenge Aimag in Northern Mongolia, logging activity and high intensity fires caused larch forest area as pure or mixed-species to decrease, while increasing birch forest area (Gradel et al. 2010). Larch forest degradation in the mountain forest steppe has been the subject of considerable research (Dulamsuren 2010a, 2010b; Dulamsuren et al. 2011; Kishigjargal et al. 2014). To our knowledge, no study has yet compared how Siberian larch and white birch are influenced by climatic factors. Studies on pine (Pinus sylvestris L.) (Haensch 2015) and birch (Gradel et al. 2017) from the western Khentey Mountains indicate that there could be differences between larch and birch, especially during spring at the peak of the fire season in Mongolia. Larch and birch vary in their ability to survive and regenerate following fires. As is the case with Scots pine, larch tends to have thicker bark providing protection from fire damage (Martinsson and Lesinski 2007). Conversely, birch is more prone to fire damage because of thinner bark, but is able to regenerate vegetatively after severe large-scale disturbances including fires (Rydberg 2000; Johansson 2008). Our general objectives in this study were: (i) to describe and understand specific responses of Siberian larch to climatic factors observed in the Mongolian mountain forest steppe zone, and (ii) to compare our results with those recently obtained for white birch observed in the same area using the same methodology (Gradel et al. 2017). Building on previous studies on larch, pine and birch in the Selenge Aimag of Mongolia (Dulamsuren et al. 2011; Haensch 2015; Gradel et al. 2015a; Gradel et al. 2017), we hypothesize that larch growth depends largely on sufficient levels of rainfall specifically in late summer and autumn of the previous year, and that temperature-growth relationships for the two species will differ during the peak fire season in spring.

\section{Methods \\ Study area}

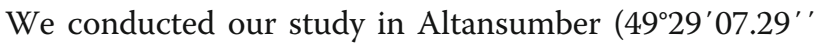
$\left.\mathrm{N} ; 105^{\circ} 31^{\prime} 30.36^{\prime \prime} \mathrm{E}\right)$ located in the province of Selenge Aimag in Northern Mongolia (Fig. 1). Situated at an elevation between 900 and $1200 \mathrm{~m}$ above sea level, the area is a prime example of the Mongolian mountain forest steppe zone. Forests consist of secondary growth stands dominated either by Siberian larch or white birch on 


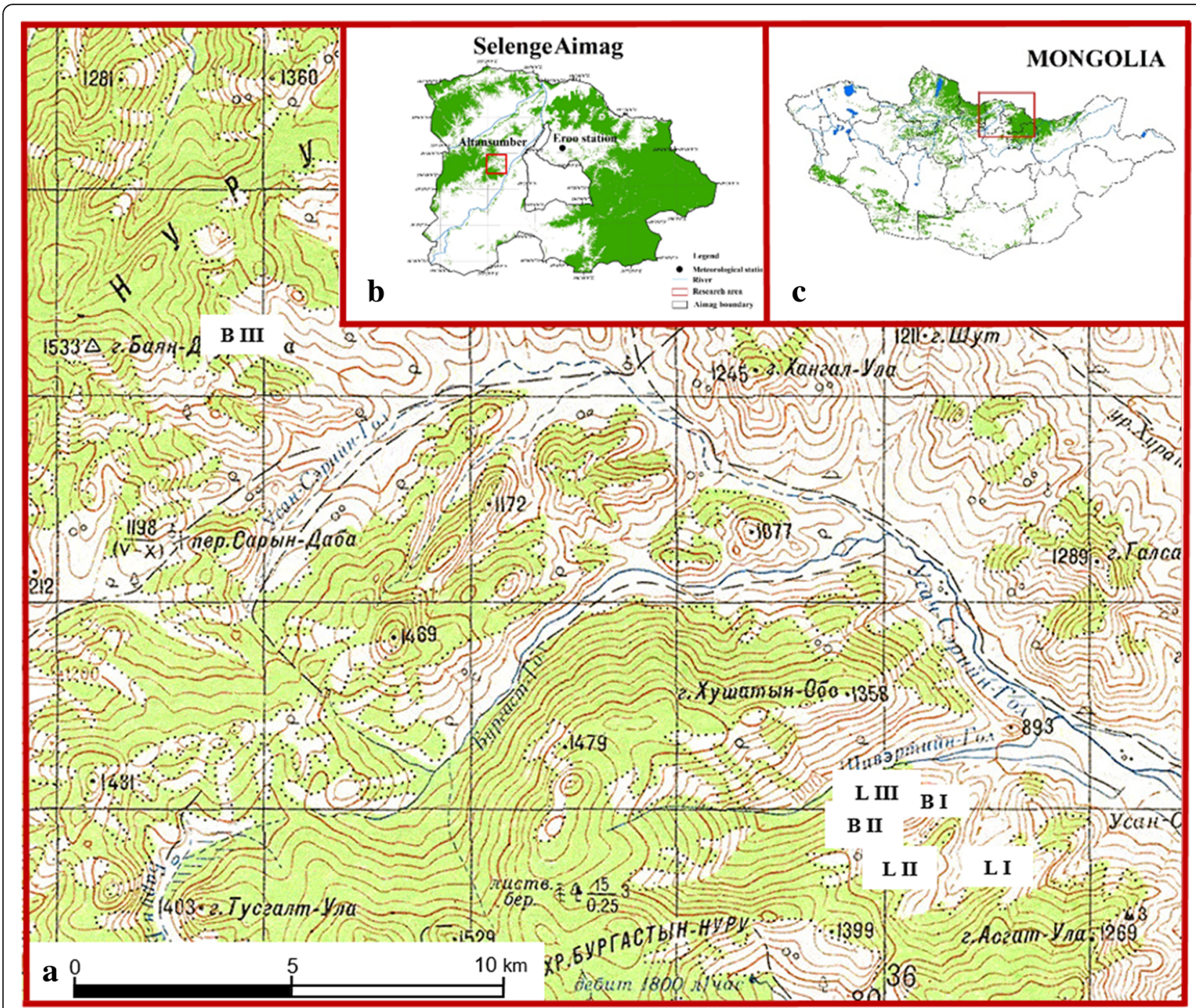

Fig. 1 a The larch stands (LI, LII, LIII) and birch stands (BI, BII, BIII) located in b) Altansumber in the Selenge Aimag in c) Northern Mongolia. (Maps: Institute of Geography-Geoecology, MAS, Ulaanbaatar and Czech-Mongolian Forest Project 2015-2017). Map elevations are in metres

north and northwest-facing slopes. Soils below larch stands in Altansumber are heavy with calcium content and with permafrost below a depth of one meter (Khutakova et al. 2016). Most stands in the study area have been affected by fire and small-scale logging activities (Gradel et al. 2015b). The area is inhabited by traditional nomads, whose livelihoods depend on raising livestock and small-scale agriculture. For our research, we sampled trees located in stands composed of $85 \%-100 \%$ larch. We established three plots within each stand in compliance with design guidelines for taiga forests (Gadow and Hui 2007). At each plot, we measured the dbh (diameter outside bark at breast height) and position of each tree above a minimum size of $7 \mathrm{~cm}$ dbh and assessed visible signs of impacts by earlier disturbances such as fires (e.g. blackened trunks) and logging (stumps). Signs of prior fires were found on all plots (Table 1).
Records for 1961-2009 from the Eroo climate station $\left(49^{\circ} 48^{\prime} \mathrm{N}, 106^{\circ} 42^{\prime} \mathrm{E}\right.$, ca. $900 \mathrm{~m}$. a.s.l.) show that mean annual temperature was $-1.8^{\circ} \mathrm{C}$ with mean monthly temperatures of $-27.1^{\circ} \mathrm{C}$ and $18.8^{\circ} \mathrm{C}$ for January and July, respectively. Mean annual precipitation was $278 \mathrm{~mm}$, 92\% of which fell almost exclusively as rain from April through September. For our analysis, we used the mean monthly temperature and monthly total precipitation.

\section{Development of the larch tree-ring chronology}

We extracted and prepared about 50 radius core samples from the three larch stands following standard dendrochronological techniques (Stokes and Smiley 1996). Cores were extracted with an increment borer of $5 \mathrm{~mm}$ in diameter at a height of $1 \mathrm{~m}$ above the ground, according to Dulamsuren et al. (2011). Cores from young trees $<45$ years were exempted from further analyses since 
Table 1 Biophysical attributes of the three Siberian larch stands in Altansumber

\begin{tabular}{llllllllll}
\hline Stand & Location (lat/long) & $\begin{array}{l}\text { Elevation } \\
(\mathrm{m} . \text { a.s.l. })\end{array}$ & Aspect & $\begin{array}{l}\text { Number } \\
\text { of plots }\end{array}$ & $\begin{array}{l}\text { Plot size } \\
\left(\mathrm{m}^{2}\right)\end{array}$ & Past disturbances & $\begin{array}{l}\text { Density } \\
\left(\text { Stems.ha }^{-1}\right)\end{array}$ & $\begin{array}{l}\text { Basal area } \\
\left(\mathrm{m}^{2} \cdot \mathrm{ha}^{-1}\right)\end{array}$ & $\begin{array}{l}\text { Mean dbh } \\
(\mathrm{cm})\end{array}$ \\
\hline LI & $49^{\circ} 28^{\prime} 57.96^{\prime \prime} \mathrm{N} / 105^{\circ} 31^{\prime} 40.95^{\prime \prime} \mathrm{E}$ & 911 & $\mathrm{NW}$ & 3 & 2500 & fire & 1389 & 15.292 & 11.0 \\
LII & $49^{\circ} 28^{\prime} 52.54^{\prime \prime} \mathrm{N} / 105^{\circ} 30^{\prime} 34.26^{\prime \prime} \mathrm{E}$ & 976 & $\mathrm{NW}$ & 3 & 2500 & fire; logg. & 565 & 23.179 & 21.8 \\
LIII & $49^{\circ} 29^{\prime} 30.34^{\prime \prime} \mathrm{N} / 105^{\circ} 30^{\prime} 29.15^{\prime \prime} \mathrm{E}$ & 913 & $\mathrm{~N}$ & 3 & 2500 & fire; logg. & 232 & 17.475 & 30.2 \\
\hline
\end{tabular}

L larch stands (85\%-100\% larch trees), LI larch stand with dominantly small diameters, LII larch stand with relatively medium diameters, LIII larch stand with relatively large diameters, fire signs of fire impact, logg. signs of previous logging (stumps)

they did not cover the whole period of the climate records. Fritts (1976) suggested that for climate studies, one core per tree is sufficient if more than 14 trees are sampled. However, for 11 trees, a second core was sampled at an angle of $90^{\circ}$ clockwise from the first core sample to control for missing and false tree rings, which are common in the semiarid environment of Mongolia (Dulamsuren et al. 2011). Each core's tree-ring widths were measured with a Megatron movable object table at a precision of $10 \mu \mathrm{m}$ and recorded with the programme Berlin Muehle 4 1.0. Preliminary evaluations of single tree-ring series were conducted using the program TSAP-Win 4.69.

Crossdating between single tree-ring series was based on Gleichläufigkeit (synchronicity) (Eckstein and Bauch 1969; Kaennel and Schweingruber 1995) and the crossdating index (CDI) which combines Gleichläufigkeit and t-values (Chichocki et al. 2004). Chronology building and evaluation of cross-correlation was conducted using the programs TSAP-Win and COFECHA 6.06P (Cook 1985). The tree-ring series were processed with a segment length of 30 years lagged successively by 15 years. We removed series which did not correlate significantly at the 99\% confidence level (threshold 0.58; taken from COFECHA). To detrend the final chronology, we used the program ARSTAN (Holmes 1983; Cook and Holmes 1986). We opted for a cubic smoothing spline with a 50\% cut-off at 10 years (Holmes et al. 1986). Statistical evaluations of the residual chronology and tree-ring series were performed with dplR 1.6.3 (Bunn 2008) in R (R Development Core Team 2015).

\section{Statistical analysis of climate-growth relationships}

The residual larch chronology was used for correlation function analysis with the climate records of monthly mean temperatures and monthly total precipitation. Radial growth activity of Siberian larch is pronounced in June and July and then decreases (Antonova and Stasova 1997). We therefore used a 15-month time window from June of the previous year to August of the current year. We also pooled the climate records according to the seasons in Mongolia (winter: November-March, spring: April-May, summer: June-August, autumn SeptemberOctober). Pearson product moment correlation coefficients were computed from 1962 to 2009 between the residual chronology and each monthly or seasonal record using the program DENDROCLIM 2002 1.0.0.1 (Biondi and Waikul 2004). For each correlation analysis, 95\% confidence intervals were derived from 1000 random bootstrapped samples (Biondi and Waikul 2004).

\section{Pointer year analysis}

Due to climate or other impact factors as natural or anthropogenic disturbances, trees can experience years with extreme growth conditions, so-called event years. These event years can trigger the development of aboveaverage wide or narrow tree rings (Schweingruber et al. 1990). We searched for such event years in our larch residual chronology. Event values were detected using the program Weiser 1.0 (García-González and Fonti 2006) with a 5-year window for the indexation (Cropper 1979). Indices obtained were compared against a threshold value of 0.3 , which corresponds to a standard deviation of $30 \%$ (Gradel et al. 2017). A positive or negative event year was identified if a respective index-value exceeded the threshold value of $|0.3|$ and if $\geq 80 \%$ cores of the residual chronology showed this tendency (Schweingruber 2012). We limited the maximum number of pointer years for one chronology to the six strongest negative and positive pointer years (Gradel et al. 2017).

We verified pointer years against our monthly and seasonal climate records over the 1962-2009 period. For seasonal climate records, evaluation values were plotted in cross diagrams. We compared Siberian larch and white birch pointer years from Altansumber (Gradel et al. 2017). Finally we created comparative diagrams that show how selected pointer years are associated with cool or warm and humid or dry conditions during prior or current year seasons.

\section{Results}

\section{Larch tree-ring chronology characteristics}

For Altansumber, we developed a larch residual chronology that extended from 1943-2009 (Fig. 2). Residual chronology statistics included an expressed population signal $>0.85$ (Table 2) indicating the residual chronology represented a theoretical population of the region (Wigley et al. 1984). Robustness of the residual chronology was confirmed with high mean values of the R-bar statistic (Table 2). Mean sensitivity and standard 


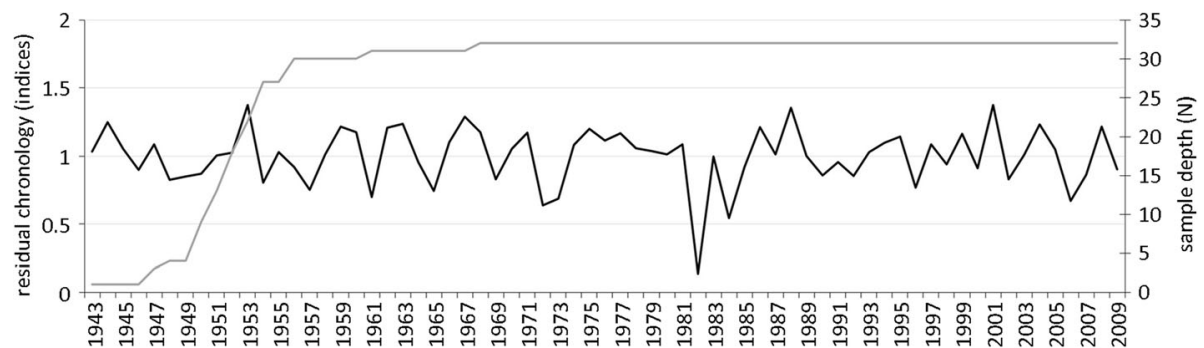

Fig. 2 Altansumber Siberian larch residual chronology ring-width indices (black curve) and sample depth or number of cores included in the chronology each year (grey curve)

deviation values indicated high year to year variability (Table 2).

\section{Climate-growth relationships}

Monthly total precipitation showed positive correlations with growth during previous year July to October and current year February to April (Fig. 3). Of these correlations, four were significant and occurred with previous year August and September and current year February and April $(p<0.05)$. Likewise, seasonal patterns of precipitation showed positive correlations with growth, particularly during previous year autumn $(p<0.05)$. In contrast, monthly mean temperature showed less pronounced negative correlations with growth except for previous year November, although the correlation was not significant. Seasonal patterns of mean temperature showed weak correlations with growth.

\section{Pointer year analysis}

Based on our threshold, we identified six positive and six negative pointer years and compared these with pointer years of young and old birch trees (Gradel et al. 2017). Consistent pointer years throughout all chronologies included 1986 and 2008 as positive pointer years and 1987 as a negative pointer year Fig. 4 .

Although we did not test for significance due to a few observations of pointer years, we found seasonal analysis of pointer years showing negative pointer years were more often associated with dry conditions both in the previous and current year.

The previous year summers of the positive pointer years were often above-average humid. Spring of the positive pointer years was rather warm and sometimes humid (Fig. 5).
Based on the selected positive versus negative pointer year comparative diagrams, 1986 and 2008 were identified as positive pointer years, showing above average monthly total precipitation during the previous and current year vegetative period (previous July-September and current May-June or May-July) (Fig. 6). Conversely, 1969 and 1996 were identified as negative pointer years showing below average monthly total precipitation during the previous and current year vegetative period (previous June-September or July-August and current March-July or April-August) (Fig. 6). No distinct pattern was identified with monthly mean temperature.

\section{Discussion}

Larch growth response to climatic factors in the mountain forest steppe

Our correlation results suggest that above-average precipitation at the end of the vegetation period of the previous year (August and September) and directly before and at the start of vegetation (February and April) of the current year is the most important climatic factor for growth of Siberian larch in the research area. A positive relationship between current-year growth and precipitation rates from the previous year measured in August and September was found in several other studies from Northern Mongolia (e.g. Dulamsuren et al. 2011; Khishigjargal et al. 2014). The late accumulation of photoassimilates during the previous year has been attributed as a positive effect on the development of earlywood in spring of the current year (Dulamsuren et al. 2011; Babushkina and Belokopytova 2014).

The pointer year analysis indicated that characteristics supporting above average growth on northern slopes in the region are: a humid summer of the previous year, followed by a relatively warm and humid spring. On the

Table 2 Siberian larch chronology statistics

\begin{tabular}{|c|c|c|c|c|c|c|c|c|}
\hline \multicolumn{6}{|c|}{ Raw chronology } & \multicolumn{3}{|c|}{ Residual chronology } \\
\hline Sample size & Length & Ring-width $(\mathrm{mm}) \pm \mathrm{SD}$ & Ov. interseries correlation & MGL (\%) & $\mathrm{AC1}$ & MS & Rbar & EPS \\
\hline 30 & 1943-2009 & $1.72 \pm 1.45$ & 0.71 & 0.75 & 0.72 & 0.36 & 0.57 & 0.97 \\
\hline
\end{tabular}

Ov. interseries correlation average correlation of each series with a master chronology (Bunn and Korpela 2014), MGL (\%) "mean Gleichläufigkeit", SD standard deviation, AC1 first-order autocorrelation, MS mean sensitivity, Rbar mean interseries correlation, EPS expressed population signal 

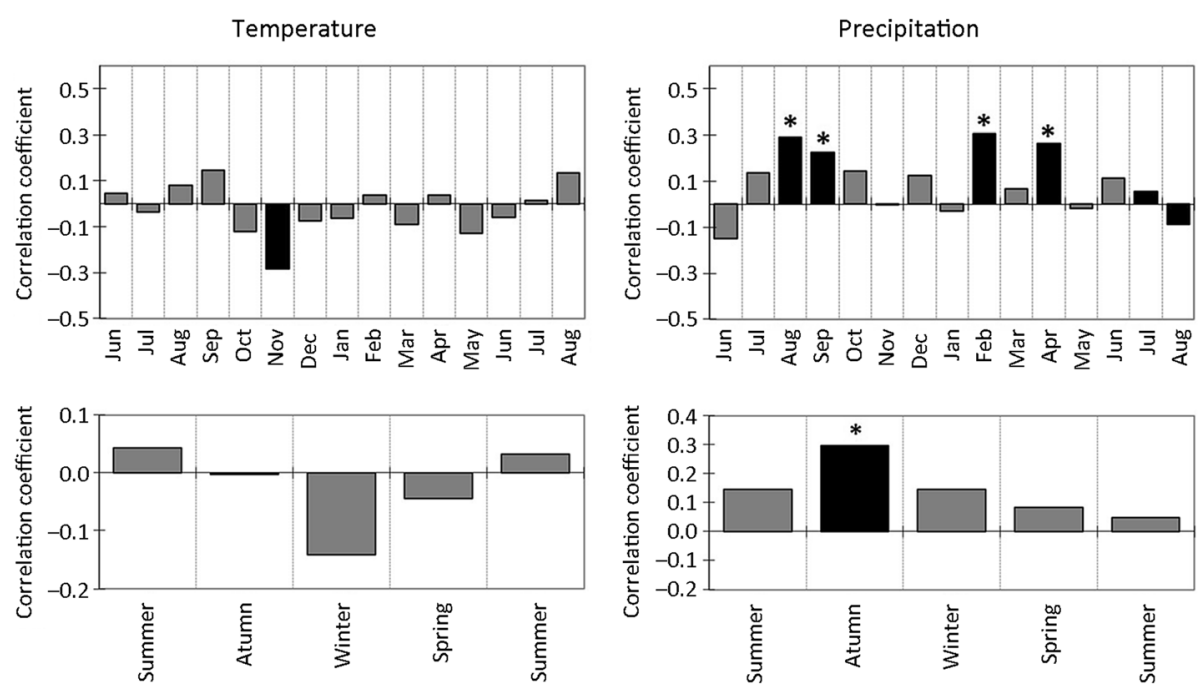

Fig. 3 Correlation coefficients of the monthly and seasonal temperature-growth and precipitation-growth relationships from 1962-2009. Black bars indicate a correlation coefficient $>0.2$ and the asterisk $\left(^{*}\right)$ indicates significance with $p<0.05$

contrary, a dry summer and autumn of the previous year, followed by a relatively dry and cool spring and a dry summer, triggered relatively low growth productivity. Previous year dry autumn weather conditions appeared to negatively affect larch growth rates.

Increased summer droughts have been denoted in previous studies as being a key factor for reduced radial growth of larch trees across the northern hemisphere (Pederson et al. 2001; Dulamsuren et al. 2010b; Khishigjargal et al. 2014; Lévesque et al. 2014). Khishigjargal et al. (2014) found that recent increases in the frequency of summer droughts have promoted the frequency of growth anomalies such as narrow latewood. In the context of the patterns of observed climate change in Mongolia (Oyuntuya et al. 2015), these results indicate that warmer and drier vegetation periods lead to lower growth productivity and may contribute to decreasing forest area. Tree growth at high elevations, however, has been shown to correlate positively with higher summer temperatures (Kolář et al. 2015; Wilson et al. 2016). Therefore, in a cold high-elevation environment with a subzero annual mean temperature, as in the Mongolian Altai
Mountains, an increase in temperature could theoretically promote the growth and productivity of larch trees (Dulamsuren et al. 2014). Drought stress has also been indirectly identified as a contributing factor to poor growth rates of larch in less continental regions. A dendrochronological study on European larch (Larix decidua Mill.) in Lithuania indicated that precipitation during the vegetation period was the most important environmental factor influencing growth during the pointer years (Vitas 2015). In this study tree-ring width of European larch positively correlated with precipitation in June and with air temperature in April and May, but showed negative correlation with air temperatures of the previous summer (Vitas 2015).

Local topographic features such as aspect in semi-arid Mongolia create a unique set of conditions during the seasonal transition (MET 2016; Xu et al. 2016), notably at the beginning and end of the vegetation period. The degree of solar radiation determined by these landscape features likely has a stronger influence during this period than during the summer. Snow melts faster, for example, on south-facing slopes than on the north-facing slopes

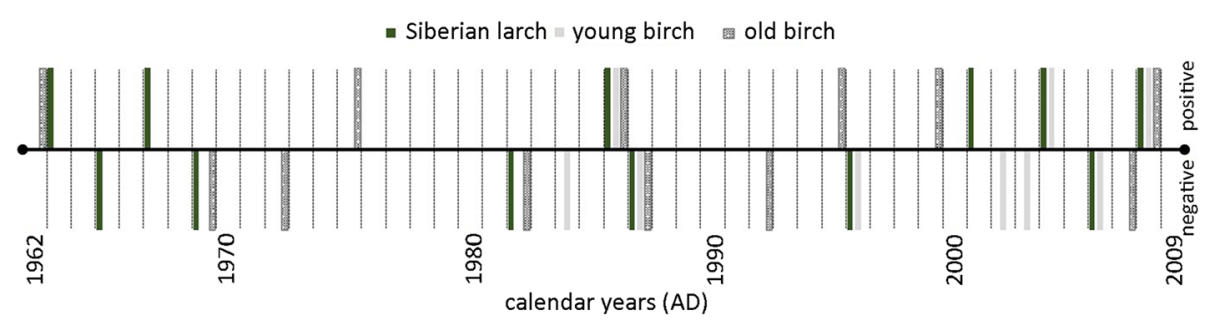

Fig. 4 Positive and negative pointer years from 1962 to 2009 for Siberian larch and young and old birch in Altansumber 

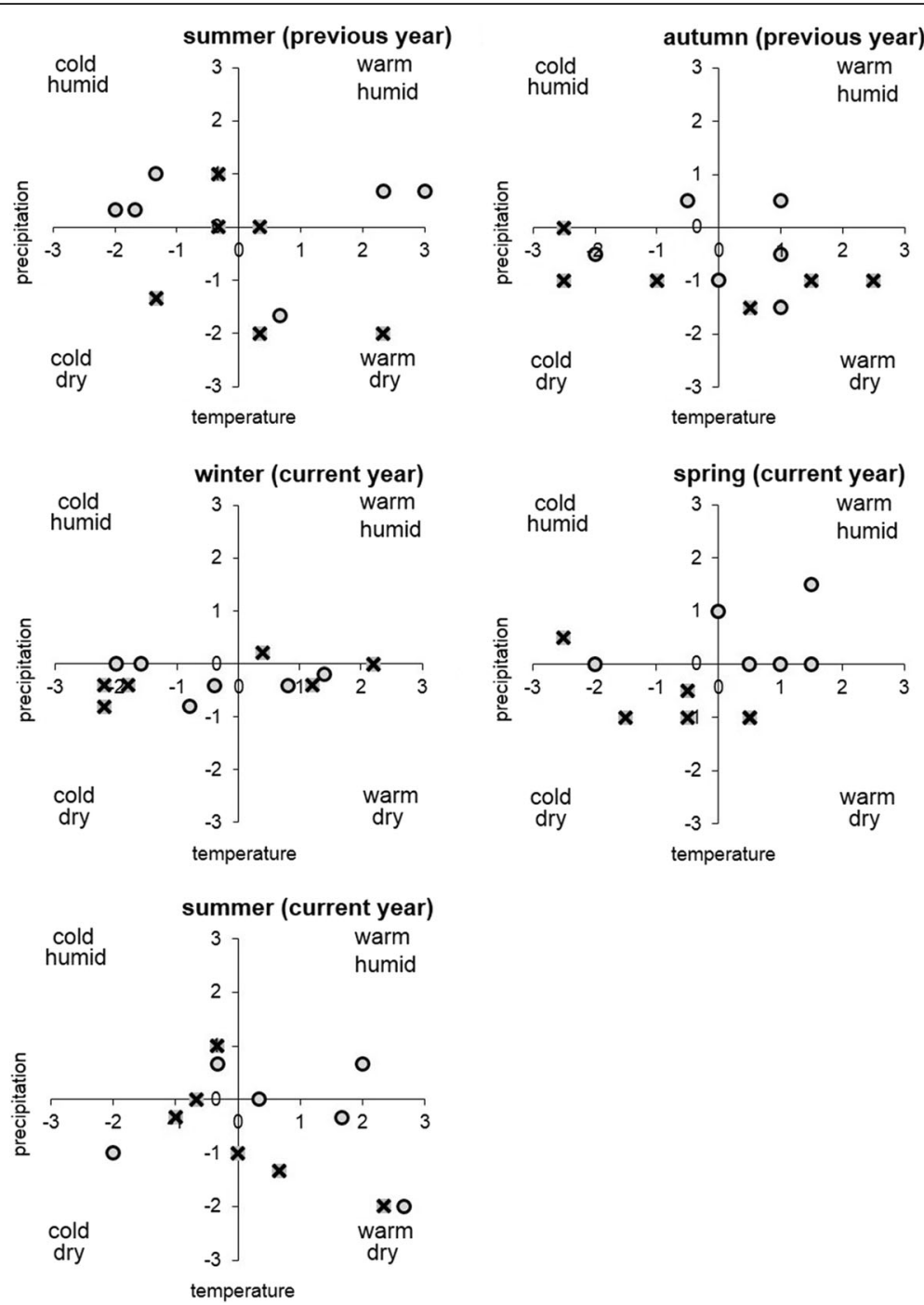

Fig. 5 Seasonal pointer years for the Siberian larch detrended chronology. Positive pointer and negative pointer years are shown as circles and crosses respectively

where the soil is kept cooler for longer periods. This may also be the case for night frost events when longer periods before sun exposure maintain coldness and humidity levels longer before the soil slowly warms. During summer the angle of the sun is high and exposition effects therefore may become less important. When a forest occurs on both south and north-facing slopes, differences in growth activity can be expected to be more pronounced (e.g. the start and end of growth, treering width). A certain mean daily threshold value of temperature is necessary to trigger cell growth, as reported by Antonova and Stasova (1997), who calculated the optimal values for larch growth in central Siberia. In this respect, interpretation of our findings is more appropriate for the stands on north-facing slopes. A more precise assessment of growth differences between trees established on both south and north-facing slopes would need to be supported by fine-scale spatial meso- and microclimate measurements (Viewegh et al. 2003; Kusbach et al. 2012).

Several studies have drawn attention to the negative impact of herbivore insects, especially the gypsy moth (Lymantria dispar L.), can have on growth of larch trees in Mongolia (Hauck et al. 2008; Dulamsuren et al. 2010a; 2011; Khishigjargal et al. 2014). Given that the survival and development of the gypsy moth population can be directly related to certain climatic factors, such as temperature especially during winter, climate-growth relationships can be indicators of insect infestations with potentially negative effects on the growth of larch trees (Dulamsuren et al. 2011). Our analysis of the climategrowth relationship presented here for larch observed in the Altansumber forest provided no indication that these stands may have suffered from insect infestation. Given 

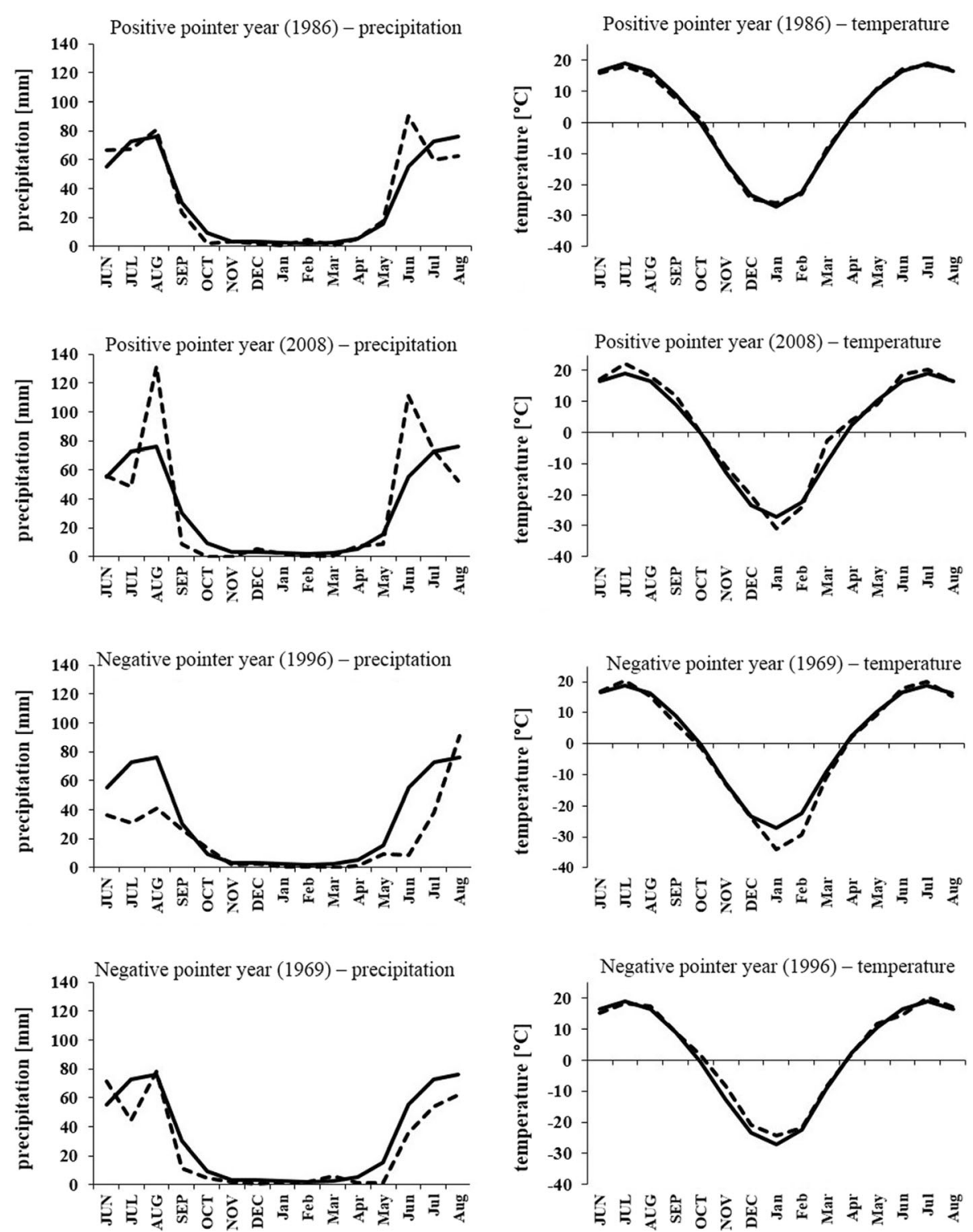

Fig. 6 Selected Siberian larch and white birch pointer years. Average course of precipitation and temperature over 1961-2009 shown as solid line. Actual course of precipitation and temperature shown as dashed line

that we were unable to identify such a specific relationship (i.e. a significant negative relationship with precipitation and temperature during the peak of winter), we can assume that insect infestation was less important for larch trees in the study area. Considering also the results of other studies (Dulamsuren et al. 2011; Gradel et al. 2017), we suggest that insect infestations in the mountain forest steppe zone may be less common compared to the taiga zone. Potential causes for this may be differences concerning the overall cover and compactness of forest patches within these zones or certain microclimatic conditions (e.g. related to specific aspects or higher accumulation of snow coverage) that can favor infestations.
The climate-growth relationship of Siberian larch compared to white birch

Despite the devastating impact of forest loss and ongoing climate change in Mongolia (MARCC 2014; Oyuntuya et al. 2015), there is only limited data available on climate-growth relationships for the two dominant tree species, Siberian larch and white birch. Comparative analyses between these two species growing in a single area do not exist so far. The comparisons we make in the present study between our results on larch and results from a previous work focused on young and mature birch trees (Gradel et al. 2017) may prove highly valuable for furthering our understanding of ecology in 
the mountain forest steppe zone. Our results strongly indicated that similarities exist between the two species. Effectively, analyses of the present study and recent work by Gradel et al. (2017) showed that precipitation is the most decisive climatic factor for both species. Many of the pointer years that were identified in the larch chronology also occurred for the chronologies of the young and/or mature birches observed in the Altansumber forest. Analysis of these years consistently provided us with a clear picture of precipitation patterns (wherein negative years indicated droughts and positive years indicated above-average precipitation; see Fig. 6 and Gradel et al. 2017). Patterns showing monthly correlation between growth and precipitation for both species also showed similarities.

However, the correlation coefficients with monthly temperature showed stronger negative, sometimes significant values for the birches, younger trees in particular. It is unlikely that birch is less well adapted to the dry and sometimes hot steppe conditions as this species populates the most southern outposts of all tree species of the Northern Mongolian steppe forests (Otoda et al. 2013; Gradel et al. 2017), notably in areas where larch have trouble surviving. The strong negative correlation of birch growth with temperatures in May (peak fire season) proved to be the most significant difference in Altansumber (Gradel et al. 2017) compared to the nonsignificant relationships drawn from our own larch chronology. We also observed differences in the growth performance between larch and birch growing in Altansumber. The growth performance and production of larch were clearly higher than those of birch in the same area (compared with Gradel et al. 2017). The mean width of tree-rings for the larch was $1.72 \mathrm{~mm} \pm 1.45$ (SD) and $0.26(\mathrm{SE})$ compared to $1.18 \mathrm{~mm} \pm 0.8(\mathrm{SD})$ and 0.17 (SE) for the young birches (average age of 30 years) and $1.03 \mathrm{~mm} \pm 0.74$ (SD) and 0.18 (SE) for the old birch trees (average age of 72 years) (Gradel et al. 2017). A very similar scenario was observed in fire-disturbed sites of mixed birch-pine stands on largely south-facing slopes of the western Khentey Mountains (taiga zone; Bugant). Data from dendrochronological examinations conducted for mean annual ring growth showed an average of 1.94 $\mathrm{mm} \pm 0.61 \mathrm{SD}$ for the pine trees, and $1.13 \mathrm{~mm} \pm 0.59$ SD for same old birch trees within the same stand (Haensch 2015). Competitive status for both species were similar. The significant negative correlation of birch growth with temperatures in April (peak fires season) proved to be the most significant difference of the climate-growth relations between the two species. No significant temperature-growth relations were found for the pine trees (Haensch 2015). This means that the comparison of temperature-growth relationships for pine and birch showed an analogous scenario resembling previously outlined relationships between larch and birch. It is worth noting, however, that an important difference between the two species was the degree of fire damage sustained on lower stems: birch trees exhibited signs of having suffered as much as eight times more fire damage than the thick barked pine trees within the same stand (Gradel et al. 2015a). Fire can damage the phloem and consequently affect transport of photoassimilates throughout a tree (Lüttge et al. 2005). Damage to the cambium can affect production and slow radial growth. While most trees are able to survive fire damage, the secondary effects can have a negative effect on growth performance for several years following. The average fire return interval in the western Khentey pine-birch forest was found to be only around 11.6 years (Oyunsanaa 2011).

\section{Indication from climate-growth relationships to species- specific sensitivity to different fire regimes}

Fire represents the most important and most frequent natural disturbance occurring throughout boreal forest ecosystems (Goldammer and Furyaev 1996), especially in Mongolia (MET 2016). Already the very first article listed in the Forest Law of Mongolia prioritizes prevention of forest and steppe fires (MOLF 2015). All sampled Siberian larch and white birch stands in Altansumber exhibited signs of previous disturbance by fire (Gradel et al. 2015b; Gradel et al. 2017). The observed differences between larch and birch in Altansumber, and similarly between pine and birch in Bugant, could in part be linked to species-specific responses to forest fires.

Fire activity in Mongolia is highest in April and May (Goldammer 2002), which also was the time for the significant negative temperature-growth relation in all birch chronologies (Haensch 2015; Gradel et al. 2017). Data from the Selenge Aimag, for example, show that more than $80 \%$ of the annual forest fire events occur in April or May (Goldammer 2002). We did not, however, find any indication that fire damage directly impacted results of the larch trees, but there is a lot of indication that it impacted birch (Gradel et al. 2017). Due to its thick bark (Martinsson and Lesinski 2007), the cambium of larch provides more protection against surface fires than that of birches. A recent study has shown the close association of fire driven ecosystems and tree species with thick bark at a global scale across different vegetation zones (Pellegrini et al. 2017). Pausas (2014) showed that the nature of the fire regime occurring within an ecosystem determines to what extent thick bark provides trees with special protection against fires. For example, there are fire regimes which are mainly selective for thick bark on the lower stem or even fire regimes dominated by high-intensity crown fires in which the resourceconsuming development of thick bark no longer offers any adaptation advantages (Pausas 2014). In contrast to 
the birch, larch has a particularly thick bark (Martinsson and Lesinski 2007), which is an important protective mechanism against surface fires. The severity of disturbances occurring in forest ecosystems is commonly described by the degree of removal of overstory trees (Puettmann and Ammer 2007). Low intensity surface fires favor the selection of fire-tolerant trees, whereas high-intensity fire events, which usually include crown fires, can prompt the stand replacement process and promote stand development by creating favorable conditions for new growth and successional stages (Goldammer and Furyaev 1996). Low intensity fires are fueled primarily by the ground cover and ground vegetation and besides climate factors the specific fuel conditions (fine fuel) have been suggested to be one potential control on the fire regime (Hessl et al. 2012). It is likely that the natural disturbance regime plays an important role in competition between birch and thick-barked conifer species. A low intensity fire regime, which usually consists of surface fires, may therefore favor the growth dominance of larch. A stand-replacing fire regime, however, may support regeneration of birch because of its re-sprouting capacity, which is a common strategy of fire resistant plants (Pausas and Verdu 2005). The nature of the fire regime therefore may selectively regulate the variety of species affected depending on the intensity, which Pausus (2014) addressed indirectly in a study on adaptive survival strategies in other regions. Anthropogenic influences increase the probability of fire events (Sheingauz 1996), given that most fires are caused by human activity (Goldammer and Furyaev 1996). The conditions for fire ignition, frequency and to some degree also severity are largely controlled by climate factors (Jolly et al. 2015). Climate change is expected to trigger more frequent and severe fire disturbances in the taiga forests (Ykhanbai 2010; Tchebakova et al. 2011). However, additional research is needed to show a clear relationship between tree species' specific growth response and fire events. Based on prior research and our results, surface fires appear to be the most plausible contributing factor for the observed differences of larch and birch growth responses.

\section{Conclusions}

Direct and indirect effects of climate change will increasingly influence the forests of Northern Asia (IPCC 2013). Our results showed that precipitation is the most decisive climate factor for growth of Siberian larch in the mountain forest steppe. Frequency and severity of disturbances (especially fire) are expected to increase (Tchebakova et al. 2011; Jolly et al. 2015). General options for maximizing the adaptive capacity of ecosystems, mentioned by the IPCC WGII for Asia, include reducing the non-climate impacts, protecting areas and habitat restoration (Hijioka et al. 2014). With reference to Mongolia current initiatives for the management of protected areas and forests are increasingly considering the impact of climate factors and disturbances (MET 2016). Research on the impact of climate factors on tree growth and disturbances can provide scientific information for developing climate and disturbance resilient forest management practices in Mongolia. We found that the main difference between larch and birch concerning sensitivity to temperature coincides with the peak of the Mongolian fire season. Eventually, furthering our knowledge of climate-growth relationships of the different tree species may support methodologies for better adapted silvicultural treatments, e.g. reforestation. Rehabilitation of larch-birch forests systematically will require advanced knowledge on species site-specific ecology. Fine-scale studies on how topography (gradient, slope and aspect) trigger the effectiveness of climate factors and disturbances (e.g. fire) and therefore influence the response of tree growth may be beneficial for the development of planning alternatives for climate resilient forest management practices.

\begin{abstract}
Acknowledgements
The plots in Altansumber were established within the UNFAO-project: "Capacity Building and Institutional Development for Participatory Natural Resources Management and Conservation in Forest Areas of Mongolia" (GCP/MON/002/NET). Field work was carried out with the Institute of Plant and Agricultural Sciences, Mongolian University of Life Sciences in Darkhan. The authors thank for financial support provided by DAAD (research grant D/12/41577). We are thankful to the Department of Wood Biology and Wood products (Universität Göttingen) and the Institute of Forest Utilization and Forest Technology (Technische Universität Dresden). We thank Albrecht Bemmann, Claus-Thomas Bues, Björn Günther, Jamsran Tsogtbaatar and the Buryat State Academy of Agriculture in Ulan-Ude. We are especially thankful to Tomas Kolár for his advice during preparation and review of this manuscript. We thank two anonymous reviewers for valuable comments on our manuscript and Aimee Orsini for linguistic corrections.
\end{abstract}

\section{Authors' contributions}

A.G. and O.N. conceived and coordinated the research project. A.G., B.G., O.N. and B.D. designed data collection. A.G. and O.N. did the field work with support of B.G. and B.D. A.G. analyzed the field data. A.G. and A.K. wrote the paper and B.G., O.N. and B.D. commented on it. All authors read and approved the final manuscript.

Competing interests

The authors declare that they have no competing interests.

\section{Author details}

${ }^{1}$ Department of Silviculture and Forest Ecology of the Temperate Zones, Universität Göttingen, Büsgenweg 1, 37077 Göttingen, Germany. ${ }^{2}$ Institute of Geography-Geoecology, Mongolian Academy of Sciences, Post Box-81, Baruun Selbe 15, Ulaanbaatar 15170, Mongolia. ${ }^{3}$ School of Agroecology and Business, Institute of Plant and Agricultural Sciences, Mongolian University of Life Sciences, P.O. Box 904, University St., Darkhan, Darkhan-Uul 45047, Mongolia. ${ }^{4}$ Department of Forest Botany, Dendrology and Geobiocoenology, Faculty of Forestry and Wood Technology, Mendel University in Brno, Zemedelská 3, 613-00 Brno, Czech Republic. 
Received: 23 March 2017 Accepted: 29 September 2017

Published online: 14 November 2017

\section{References}

Antonova GF, Stasova W (1997) Effects of environmental factors on wood formation in larch (Larix sibirica Ledeb.) stems. Trees 11(8):462-468. doi:10. 1007/PL00009687

Antropov VF, Seredkin AD, Shhepin AA (2013) Forestry of Buryatia. In: Krivosheev NP, Egorova AYu (eds) Ulan-Ude: EKOS, p 184 (in Russian)

Babushkina EA, Belokopytova LV (2014) Climatic signal in radial increment of conifers in forest-steppe of southern Sibiria and its dependence on local growing conditions. Russ J Ecol 45(5):325-332

Biondi F, Waikul K (2004) DENDROCLIM2002: A C++ program for statistical calibration of climate signals in tree-ring chronologies. Comput Geosci 30:303-311

Bunn A, Korpela M (2014) An Introduction to DplR. Available via DIALOG. https:// cran.r-project.org/web/packages/dpIR/vignettes/intro-dpIR.pdf. Accessed 10 Jun 2015

Bunn AG (2008) A dendrochronology program library in R (dpIR). Dendrochronologia 26(2):115-124

Chichocki O, Bichler M, Firneis G, Kutschera W, Müller W, Stadler P (2004) The Synchronization of Civilizations in the Eastern Mediterranean in the Second Millenium BC: Natural Science Dating Attempts. In: Buck CE, Millard A (eds) Tools for constructing Chronologies: Crossing disciplinary boundaries. Springer, p 260

Cook ER (1985) A time series analysis approach to tree ring standardization. Dissertation. University of Arizona, Faculty of the School of Renewable Natural Resources, p 171

Cook ER, Holmes RL (1986) User's manual for program ARSTAN. In: Holmes RL, Adams RK, Fritts HC (eds) Tree-ring Chronologies of Western North America: California. Eastern Oregon and Northern Great Basin. University of Arizona, Tucson, pp 50-56

Cropper JP (1979) Tree-ring skeleton plotting by Computer. Tree-Ring Bull 39:47-59

Cui G, Kwak H, Choi S, Kim M, Lim CH, Lee WK, Kim JS, Chae Y (2016) Assessing vulnerability of forests to climate change in South Korea. J Forest Res 27(3): 489-503. doi:10.1007/s11676-015-0201-2

Dorjsuren C (2014) Forest Ecosystems (in Climate change impact and exposure) Published in: Mongolia second assessment report on climate change MARCC 2014. Ulaanbaatar, pp 94-100

Dulamsuren C, Hauck M, Leuschner HH, Leuschner C (2010a) Gypsy mothinduced growth decline of Larix sibirica in a forest-steppe ecotone. Dendrochronologia 28(4):207-213

Dulamsuren C, Hauck M, Leuschner C (2010b) Recent drought stress leads to growth reductions in Larix sibirica in the western Khentey, Mongolia. Glob Change Biol 16:3024-3035

Dulamsuren C, Hauck M, Leuschner HH, Leuschner C (2011) Climate response of tree ring width in Larix sibirica growing in the drought-stressed forest-steppe ecotone of northern Mongolia. Ann For Sci 68(2):275-282. doi:10.1007/ s13595-011-0043-9

Dulamsuren C, Khishigjargal M, Leuschner C, Hauck M (2014) Response of treering width to climate warming and selective logging in larch forests of the Mongolian Altai. J Plant Ecol 7(7):24-38. doi:10.1093/jpe/rtt019

Eckstein D, Bauch J (1969) Beitrag zur Rationalisierung eines dendrochronologischen Verfahrens und zur Analyse seiner Aussagesicherheit. Forstwiss Centralbl 88(1):230-250

Fritts H (1976) Tree Rings and Climate. London, New York, San Francisco: Academic Press, 1st ed, p 567

Gadow Kv, Hui GY (2007) Can the species-area relationship be derived from prior knowledge of the tree species richness? Forest Stud 46:13-22

García-González I, Fonti P (2006) Selecting earlywood vessels to maximize their environmental signal. Tree Physiol 26(10):1289-1296

Goldammer (2002) Fire situation in Mongolia. IFFN No. 26 - January 2002, p 7583. Global Fire Monitoring Center, Freiburg. http://www.fire.uni-freiburg.de/ iffn/country/mn/mn_11.htm. Accessed 22 Mar 2017

Goldammer JG, Furyaev W (1996) Fire in Ecosystems of Boreal Eurasia: Ecological Impacts and Links to the Global System. In: Goldammer JG, Furyaev W (eds) 1996: Fire in Ecosystems of Boreal Eurasia. Kluwer Academic Publishers. Dordrecht, Boston, London, pp 1-20

Gradel A, Haensch C, Batsaikhan G, Batdorj D, Ochirragchaa N, Günther B (2017) Response of white birch (Betula platyphylla Sukaczev) to temperature and precipitation in the mountain forest steppe and taiga of northern Mongolia. Dendrochronologia 41: 24-33. doi:10.1016/j.dendro.2016.03.005
Gradel A, Nemitz D, Guryanov M (2010) Anthropogenic drivers of biodiversity change in the mountain forest steppe of Mongolia. Input of the APMN community to the tenth meeting of the CoP on biodiversity in Nagoya, Japan, 18-29 Dec 2010. Asia Pacific Mountain Courier 10(2):1-4

Gradel A, Ochirragchaa N, Altaev AA, Voinkov AA (2015a) Non-spatial structure of light taiga, damaged by surface fires in the Khentii Mountains (research area Bugant, Northern Mongolia). Paper presented at an international conference in: Kalashnikov IA, Zydypov RZ, Ton SKA, Ilin YM, Dardshaev VK, Numaeva MN, Kalashnikov KI (eds) Earth and Water Resources: Monitoring the Ecological and Economic Condition and Models of Governance: International Scientific Conference. Buryat State Academy of Agriculture named after V.R. Philipov, Ulan-Ude, 23-25 April 2015, pp 198-203. (in Russian)

Gradel A, Ochirragchaa N, Altaev AA, Voinkov AA, Enkhtuya B (2015b) Spatial distribution of trees on light taiga plots before selective thinning. Mongolian J Agric Sci 15(2):91-99

Haensch C (2015) Dendroklimatologische Untersuchung an Mandschurischer Birke (Betula platyphylla Suk.) und Wald-Kiefer (Pinus sylvestris L.) im Khentii-Gebirge, Mongolei. Master thesis, Technische Universität Dresden, Dresden, s106

Hansen MC, Potapov PV, Moore R, Hancher M, Turubanova SA, Tyukavina A, Thau D, Stehman SV, Goetz SJ, Loveland TR, Kommareddy A, Egorov A, Chini L, Justice CO, Townshend JRG (2013) High-resolution global maps of 21stcentury forest cover change. Science 342:850-853

Hauck M, Dulamsuren C, Heimes C (2008) Effects of insect herbivory on the performance of Larix sibirica in a forest-steppe ecotone. Environ Exp Bot 62: 351-356. doi:http://dx.doi.org/10.1016/j.envexpbot.2007.10.025

Hessl AE, Ariya U, Brown P, Byambasuren O, Green T, Jacoby G, Sutherland EK, Baatarbileg N, Maxwell RS, Pederson N, De Grandpré L, Saladyga T, Tardif JC (2012) Reconstructing fire history in central Mongolia from tree-rings. Int J Wildland Fire 21(1):86-92

Hijioka YE, Lin JJ, Pereira CRT, Cui X, Insarov GE, Lasco RD, Lindgren E, Surjan A (2014) Asia. Climate Change 2014: Impacts, Adaptation, and Vulnerability. Part B: Regional Aspects. Contribution of Working Group II to the Fifth Assessment Report of the Intergovernmental Panel on Climate Change. In: Barros VR, Field CB, Dokken DJ, Mastrandrea MD, Mach KJ, Bilir TE, Chatterjee M, Ebi KL, Estrada YO, Genova RC, Girma B, Kissel ES, Levy AN, MacCracken S, Mastrandrea PR, White LL (eds) . Cambridge University Press, Cambridge, United Kingdom and New York, pp 1327-1370

Holmes RL (1983) Computer-assisted quality control in tree-ring dating and measurement. Tree-Ring Bull 43:69-75

Holmes RL, Adams RK, Fritts HC (1986) Tree-ring Chronologies of Western North America: California, Eastern Oregon and Northern Great Basin with Procedures in the Chronology Development Work including Users Manuals for Computer Programs Cofecha and Arstan. Laboratory of Tree-Ring Research, University of Arizona, Tucson, Arizona. Chronology Series VI, p 182

IPCC (2013) Summary for Policymakers. Climate Change 2013: The Physical Science Basis. Contribution of Working Group I to the Fifth Assessment Report of the Intergovernmental Panel on Climate Change. In: Stocker TF, Qin D, Plattner G-K, Tignor M, Allen SK, Boschung J, Nauels A, Xia Y, Bex V, Midgley PM (eds) Cambridge University Press. Cambridge, United Kingdom and New York, NY, USA. http://www.ipcc.ch/pdf/assessment-report/ar5/wg1/ WG1AR5_SPM_FINAL.pdf. Accessed 22 Jun 2017

Johansson T (2008) Sprouting ability and biomass production of downy and silver birch stumps of different diameters. For Ecol Manage 32 (10): 944-951. https://doi.org/10.1016/j.biombioe.2008.01.009, Accessed 22 Jun 2017

Jolly WM, Cochrane MA, Freeborn PH, Holden ZA, Brown TJ, Williamson GJ, Bowman DMJS (2015) Climate-induced variations in global wildfire danger from 1979 to 2013. Nat Commun 6:7537. doi:10.1038/ncomms8537

Kaennel M, Schweingruber FH (eds) (1995) Multilingual Glossary of Dendrochronology. Terms and Definitions in English, German, French, Spanish, Italian. Portugese and Russian. Paul Haupt, Bern, p 467

Khishigjargal M, Dulamsuren C, Leuschner HH, Leuschner C, Hauck M (2014) Climate effects on inter- and intra-annual larch stemwood anomalies in the Mongolian forest-steppe. Acta Oecon 55:113-121

Khutakova SV, Ubugunova VI, Gradel A, Enkhtuya B (2016) Morphogenetic features of soils of larch forests of terrain Altan Sumber Orkhon-Selenga Middle Mountain. International Conference on "Central Asian Environmental and Agricultural Problems, Potential Solutions" Institute of Plant and Agricultural Sciences, School of Agroecology and Business of the MULS in Darkhan, 21 -22 April 2016, Darkhan Uul, Mongolia, pp $127-$ 130 (in Russian) 
Kolář T, Čermák P, Oulehle F, Trnka M, Štěpánek P, Cudlín P, Hruška J, Büntgen U, Rybníček M (2015) Pollution control in the 1980s contributed to unprecedented spruce growth in the "Black Triangle" near the CzechPolish border. Sci Total Environ 538:703-711. doi:10.1016/j.scitotenv.2015. 08.105

Kopp BJ, Lange J, Menzel L (2016) Effects of wildfire on runoff generating processes in northern Mongolia. Reg Environ Change (2 May 2016). doi:10. 1007/s10113-016-0962-y

Kopp BJ, Minderlein S, Menzel L (2014) Soil moisture dynamics in a mountainous headwater area in the discontinuous permafrost zone of northern Mongolia. Arct Antarct Alp Res 46(2):459-470 https://doi.org/10.1657/1938-4246-46.2. 459. Accessed 23 Mar 2017

Kraznoshekov YN (2013) Soil cover and soils of Mountain forests of Northern Mongolia. Genesis Geogra Soils 7:694-703

Kusbach A, Long JM, van Miegroet H, Shultz ML (2012) Fidelity and diagnostic species concepts in vegetation classification in the Rocky Mountains, northern Utah, USA. Botany 90(8):678-693

Lévesque M, Rigling A, Bugmann H, Weber P, Brang P (2014) Growth response of five co-occurring conifers to drought across a wide climatic gradient in Central Europe. Agr For Meteorol 197(6):1-12

Lindner M, Maroschek M, Netherer S, Kremer A, Barbari A, Gonzalo JG, Seidl R, Delzon S, Corona P, Kolström M, Lexer MJ, Marchetti M (2010) Climate change impacts, adaptive capacity, and vulnerability of European forest ecosystems. For Ecol Manag 259(4):698-709

Lüttge U, Kluge M, Bauer G (2005) Botanik. 5, Aufl. Wiley-VCH Verlag GmbH \& Co. KgaA, Weinheim, p 65

MARCC (2014) Mongolian Second Assessment Report on Climate Change. Ministry of Environment and Green Development of Mongolia, Ulaanbaatar, p 302

Martinsson O, Lesinski J (2007) Siberian larch - Forestry and Timber in a Scandinavian Perspective. Jämtlands County Council Institute of Rural Development, Sweden, p 91

MET (Ministry of Environment and Tourism) (2016) Multipurpose National Forest Inventory 2014-2016, 1st edn. Ministry of Environment and Tourism, Ulaanbaatar, Mongolia

MOLF (2015) The purpose of this law is to regulate relations on protection, restoration, afforestation, possession, use of forests and prevention from forest and steppe fires (in Mongolian). http://www.legalinfo.mn/law/details/ 12171, Accessed 23 Mar 2017

Mühlenberg M, Appelfelder J, Hoffmann H, Ayush E, Wilson KJ (2012) Structure of the montane taiga forests of West Khentii, Northern Mongolia. J Forest Sci 58(2):45-56

Natsagdorj L (2014) Climate change adaptation strategy and measures. Published in: Mongolia second assessment report on Climate Change - MARCC 2014 Ulaanbaatar, p 183-202

Otoda T, Sakamoto K, Hirobe M, Undarmaa J, Yoshikawa K (2013) Influences of anthropogenic disturbances on the dynamics of white birch (Betula platyphylla) forests at the southern boundary of the Mongolian forest-steppe. J For Res 18:82-92

Oyunsanaa B (2011) Fire and stand dynamics in different types of the West Khentey Mountains. Georg-August-Universität Göttingen, Mongolia. Dissertation, p 119

Oyuntuya S, Dorj B, Shurentsetseg B, Bayarjargal E (2015) Agrometeorological information for the adaptation to climate change. In: Badmaev NB, Khutakova CB (eds) Soils of Steppe and Forest Steppe Ecosystems of Inner Asia and Problems of Their Sustainable Utilization: International Scientific Conference. Buryat State Academy of Agriculture named after V.R. Philipov, Ulan-Ude, pp 135-140

Pausas JG (2014) Bark thickness and fire regime. Funct Ecol 29(3):315-327. doi:10. $1111 / 1365-2435.12372$

Pausas JG, Verdu M (2005) Plant persistence traits in fire-prone ecosystems of the Mediterranean basin: a phylogenetic approach. Oikos 109:196-202

Pederson N, Jacoby GC, D'Arrigo RD, Cook ER, Buckley B, Dugarjav C, Mijiddorj R (2001) Hydrometeorological reconstructions for northeastern Mongolia derived from tree- rings: 1651-1995. J Climate 14:872-881

Pellegrini AF, Anderegg WRL, Paine CET, Hoffmann WA, Kartzinel T, Rabin SS, Sheil D, Franco AC, Pacala SW (2017) Convergence of bark investment according to fire and climate structures ecosystem vulnerability to future change. Ecol Lett 20(3):307-316. doi:10.1111/ele.12725

Puettmann KJ, Ammer (2007) Trends in North American and European regeneration research under the ecosystem management paradigm. Eur J Forest Res 126(1):1-9
R Development Core Team (2015) R Version 3.1.0: The R Project for Statistical Computing. http://www.r-project.org. Accessed 20 Jun 2015

Rydberg D (2000) Initial sprouting, growth and mortality of European aspen and birch after selective coppicing in central Sweden. For Ecol Manage 130 (1-3): 27-35. https://doi.org/10.1016/S0378-1127(99)00187-5. Accessed 23 Mar 2017

Schweingruber FH (2012) Der Jahrring-Standort, Methodik. Zeit und Klima in der Dendrochronologie. Verlag Kessel, Remagen-Oberwinter, p 234

Schweingruber FH, Eckstein D, Serre-Bachet F, Bräker OU (1990) Identification, presentation and interpretation of event years and pointer years in dendrochronology. Dendrochronologia 8:9-38

Sheingauz AS (1996) The Role of Fire in Forest Cover, Structure, and Dynamics in the Russian Far East. In: Goldammer JG, Furyaev W (eds) Fire in Ecosystems of Boreal Eurasia. Kluwer Academic Publishers, Dordrecht, pp 186-190

Stokes MA, Smiley TL (1996) An Introduction to Tree-Ring Dating. Tucson : Univ. of Arizona Press, p 73

Swanson D (1996) Susceptibility of permafrost soils to deep thaw after forest fires in interior Alaska, U.S.A., and some ecological implications. Arct Alp Res 28(2): 217-227. doi:10.2307/1551763

Tchebakova NM, Parfenova El, Soja AJ (2011) Climate change and climateinduced hot spots in forest shifts in central Siberia from observed data. Reg Environ Change 11(4):817-827. doi:10.1007/s10113-011-0210-4

Tikhonova IV, Korets MA, Mukhortova L (2014) Potential Soil and Climatic Ranges of Pine and Larch in Central Siberia. Contemp Probl Ecol+ 7(7):752-758. doi: 10.1134/S1995425514070130

Viewegh J, Kusbach A, Mikeska M (2003) Czech forest ecosystem classification. Journal of Forest Science 49(2):85-93 http://www.agriculturejournals.cz/ publicFiles/55710.pdf. Accessed 23 Mar 2017

Vitas A (2015) A dendroclimatological analysis of European larch (Larix decidua Mill.) from Lithuania. Balt For 21(1):65-72

Wigley TML, Briffa KR, Jones PD (1984) On the average value of correlated time series, with applications in dendroclimatology and hydrometeorology. J Clim Appl Meteorol 23:201-213

Wilson R, Anchukaitis K, Briffa KR, Büntgen U, Cook E, D'Arrigo R, Davi N, Esper J, Frank D, Gunnarson B, Hegerl G, Helama S, Klesse S, Krusic PJ, Linderholm HW, Myglan V, Osborn TJ, Rydval M, Schneider L, Schurer A, Wiles G, Zhang P, Zorita E (2016) Last millennium northern hemisphere summer temperatures from tree rings: Part I: The long term context (Review). Quaternary Sci Rev 134:1-18 https://doi.org/10.1016/j.quascirev.2015.12.005. Accessed 23 Mar 2017

Xu C, Liu H, Anenkhonov OA, Korolyuk A, Sandanov D, Balsanova LD, Naidanov BB, Wu X (2016) Long-term forest resilience to climate change indicated by mortality, regeneration, and growth in semiarid southern Siberia. Glob Change Biol 23(6):2370-2382. doi:10.1111/geb.13582

Ykhanbai H (2010) Mongolian forestry outlook study. Asia-Pacific forestry sector outlook study II. Working paper series. No. APFSOS II/ WP/ 2009/ 21 FAO. Bangkok, 2010, p 49

\section{Submit your manuscript to a SpringerOpen ${ }^{\mathcal{O}}$ journal and benefit from:}

- Convenient online submission

- Rigorous peer review

- Open access: articles freely available online

- High visibility within the field

- Retaining the copyright to your article

Submit your next manuscript at springeropen.com 